\title{
Implications of Water Tariff Structures on Water Demand in Santa Cruz Island (Galapagos Archipelago)
}

\section{Maria F. Reyes}

Environmental Engineering and Water Technology Department, IHE Delft (Institute for Water Education), Netherlands

Email: mf.reyesperez@gmail.com

\author{
Article History \\ Received: 2 July, 2021 \\ Revised: 25 August, 2021 \\ Accepted: 13 September, 2021 \\ Published: 18 September, 2021 \\ Copyright (c) 2021 ARPG \& \\ Author \\ This work is licensed under the \\ Creative Commons Attribution \\ International \\ (a) (i) CC BY: Creative \\ Commons Attribution License \\ 4.0
}

\begin{abstract}
The island of Santa Cruz, located in the Galápagos Archipelago has experienced a significant increase in tourism with consequent growth of the local population over the past two decades. The rapid increase in the number of hotels and restaurants raised pressure on the water demand needed to satisfy the customers' needs. The municipality of Santa Cruz has not been capable of coping with current expansion rates in order to provide good quality water services. Financial constraints, limited personnel, and tariff structures are the main reasons that restrict the capacity of the Department of Potable Water and Sanitation (DPWS) to manage the water supply system. There are two main settlements on the island are Puerto Ayora and its suburb, Bellavista, with a total population of approximately 14,500 and independent water supply systems. Puerto Ayora has a fixed-priced tariff per month, for categories established by the municipality. On the other hand, Bellavista has a metered system, with fixed consumer costs Yet, approximately $32 \%$ of water meters are faulty. Consequently, water demand in these two settlements varies significantly, which is likely influenced by the difference in tariff structures. This manuscript assesses the difference in tariffs between the two settlements. Furthermore, the impacts on revenues due to faulty meters (Bellavista) and fixed tariffs (Puerto Ayora) are quantified. In addition, several scenarios have been developed and analyzed in order to examine the benefits. Finally, the information regarding overdue bills and willingness to pay by the different categories of users has been examined. Results show that the revenues from water supply vary extensively between the two settlements. Due to the fixed tariffs in Puerto Ayora, the estimated cost per cubic meter of water varies depending on the specific category and estimated quantities of water used. In the case of Bellavista, water meters should be managed better and have regular maintenance. The high percentage of faulty meters gives an extra deficit to the municipality.
\end{abstract}

Keywords: Water tariff; Water demand: Water supply; Galápagos Islands; Tropical islands.

\section{Introduction}

The exponential growth of local population and consequent tourist visitors (Bailey and Buckley, 2005) over the last two decades on the Galápagos Islands has caused several impacts. One of the most significant ones is the dramatic increase on water demand, especially on the island of Santa Cruz, which holds $60 \%$ of the total population of the archipelago (INEC, 2010). Even though the municipal water supply system came into operation in the 1980's with the objective of providing of proper water supply, it has failed to optimally serve local population in terms on quantity and quality.

The municipal water supply system has not been able to cope with current expansion rates in Santa Cruz island. The main issues with this water supply system is that it is unreliable and intermittent. Moreover, the supplied water is not apt for human consumption due to high chloride levels (Banerjee et al., 2010) from brackish water sources and high levels of feacal coliforms (Boland and Whittington, 1998), due to the proximity of septic tanks to water sources. In addition, the shortage of water has obliged the local population to seek for alternative sources like bottled-desalinated water for drinking purposes, buying of brackish-water from trucks and rainwater harvesting. Due to the intermittency of the service, local population has also resourced to different types of storages in form of elevated tanks and/or cisterns.

The municipality of Santa Cruz is in charge of the two separate water supply networks for each of the main urban settlements on the island: Puerto Ayora and Bellavista. The water tariff structures vary significantly among the settlements, for instance, Puerto Ayora has a fixed-tariff per month due to the absence of water meters installed on individual premises, while Bellavista has a consumption-based tariff based on water meter readings. Financial constraints, limited personnel, under-pricing of water, among other reasons, have restricted the capacity of the Department of Potable Water and Sanitation (DPWS) to ameliorate the water supply service. Moreover, the current 
water tariffs are low and highly subsidized, impacting the revenues of the municipality and therefore, the improvement of water supply.

The purpose of this paper is to assess how the current issues are affecting the municipality in financial terms. Several changes to the water tariffs are proposed, as means to increase revenues from water supply. Also, the paper aims to analyze the financial impacts due to faulty meters in Bellavista and fixed tariffs in Puerto Ayora. Furthermore, water tariffs are reviewed in depth in order to compare the implications and consequences of the different tariff structures. In addition, several scenarios on the increasing of tariff values, as well as the improvement of water meter management are evaluated. Finally, the information regarding overdue bills and willingness to pay by different categories of users have been examined, as well as the economical impacts of the application of an Increasing Block Tariff (IBT) and Linear Tariff on both settlements. Similarly, the financial implication of the installation of a desalination plant as part of the centralized system and the increase of costs of water is portrayed and analyzed.

\section{Water Tariffs in Developing Countries}

Setting up water tariffs is a challenging task, especially in developing countries. The main challenge that has been confronted by several water utilities is the fair access to water services by the poorer population. Usually, this part of the population tends to be mostly affected by regional or national water policies. According to (Zetland and Gasson, 2013), if the price of water is below the full cost of providing the service, unsustainable water demand will increase. The main consequence of under-pricing of water is the stress caused on supply systems, such as intermittency of the service due to insufficient revenues and suspension of maintenance procedures.

Scarcity of water resources is not only due to natural causes, but also due to the development of policies on subsidized and under-priced water. Consequently, this encourages exorbitant water use and lack of environmental awareness. According to d'Ozouville and Merlen (2007), water prices at least need to cover operating and capital costs; nevertheless, some countries deal with water and sanitation as a political priority based on limited budget distributions. As a result, scarcity is provoked through political processes (Direccion del Parque Nacional Galapagos, 2014). According to Banerjee et al. (2010) water systems in developing countries must provide services that are safe, desirable, and affordable to consumers, and also behave as commercial systems which can be capable of recovering costs. The most common way of doing so has been the establishment of water tariffs, which have been intended to sustain utilities' operations.

Like any other business, water utilities need to recover the costs, in order to sustain their operations throughout time, by developing tariffs for the consumers. These water tariffs are usually set below full recovery of costs for many reasons ranging from historical to political, meaning that several countries have significant implicit or explicit subsidies (Gobierno Autonomo Descentralizado del Municipio de Santa Cruz, 2013). There have been several types of tariffs identified in developing countries: (i) volumetric - water metering is applied; and this subdivides into (a) Increasing Block Tariffs (IBT) - prices increase with higher consumption, (b) linear - proportional to consumption, (c) decreasing block tariff - price decreases with higher consumption, (ii) fixed/flat rate - no metering is applied and (iii) free water- no payment at all (Liu, 2011).

Many developing countries, such as in Africa, use more often the IBT. According to Banerjee et al. (2010), this type of tariff refers to the increase of price with the increase of volume. The objective of this tariff is to set the first block at a very low price in order to protect poor households, who are assumed to consume less than non-poor households. Thus, most water utilities using this tariff are able to recover operations and management costs at the highest block tariffs, which are the higher consumers (Mena et al., 2013). Many countries in Africa have also adopted a two-part tariff structure which includes a fixed one and also a water-consumption-based charge. In other developing countries, the most common water tariff is linear, with a fixed price per cubic meter.

Setting a tariff for water services has been a useful tool with several objectives regarding economic, environmental and social issues. In order for it to be efficient, it must involve a price which provides benefits of water use and conservation to the consumers (Reyes et al., 2015). Therefore, the established prices should not only consider financial costs, but externalities that the use of water enforces on the environment, as well as on the economy. Also, an efficient tariff should ensure water for all socioeconomic groups, as well as environmental awareness of water use among the consumers.

\section{The Case of Santa Cruz Island}

The water tariff issues on Santa Cruz have been generally addressed as a financial one, but is also political. Municipal authorities have not increased water tariffs or installed water meters in Puerto Ayora fearing a possible rejection and discontent from local population, due to the current low service. Since the service is perceived as inefficient, water authorities have explained that the population may protest showing their dissatisfaction if the water prices change. However, without the modification of current tariffs, the municipality may not have the sufficient financial resources to improve the system as local population expects and needs.

The water tariffs per category were established by the municipality based on a regulation in developed in the year 2000 and then modified in 2004, pricing the water services on the island of Santa Cruz. Furthermore, a complementary regulation established new prices for the service, as well as an increase of $10 \%$ every six months, starting from January 2005. However, in 2006 a resolution was developed to stop the biannual increase of costs, fixing the price and maintaining it until nowadays. Consequently, the collected revenues do not cover even the operation and maintenance costs fully, causing a deficit that needs to be subsidized by the municipality. 
Current water tariffs in Santa Cruz have a significant subsidy from the municipality, similarly as in many other cities in Ecuador, where an economical model predominates based on subsidies for basic services and resources (such as gas, fuel, water, etc.). As a consequence of this high subsidy model, the revenues collected by the water department does not cover the expenditures of the municipality for supplying the resource.

Bellavista, a small town in Santa Cruz Island with its own water supply network, has a consumption-based tariff of 1.21 USD per cubic meter of water consumed. However, a high percentage of water meters in this settlement are faulty and have been identified as registering no consumption (32\% in 2013), contributing to lower income for the municipality and generating significant financial losses. On the other hand, the fixed water-tariff structures in Puerto Ayora vary per category, regardless of the volume consumed. In addition to this, there are no water meters installed within the premises, therefore, actual consumption is unknown. Table 1 shows different consumer categories in Puerto Ayora according to the Municipality of Santa Cruz and the corresponding fixed monthly water tariff .

Table-1. Consumer categories and water prices for Puerto Ayora according to the Municipality of Santa Cruz

\begin{tabular}{l|l|l}
\hline Category & $\begin{array}{l}\text { Number of } \\
\text { connections* }\end{array}$ & $\begin{array}{l}\text { Fixed Water } \\
\text { Price/month) }\end{array}$ \\
\hline Domestic (less than $100 \mathrm{~m}^{2}$ of area) & 1,146 & 5.24 \\
\hline $\begin{array}{l}\text { Commercial (more than } 100 \mathrm{~m}^{2} \text { of area } \\
\text { and restaurants) }\end{array}$ & 932 & 11.24 \\
\hline Industrial (Big hotels and laundries & 21 & 45 \\
\hline Residential (small hotels) & 20 & 28.50 \\
\hline Official & 28 & 6.12 \\
\hline *Up to December 2013 &
\end{tabular}

Based on a previous research, fixed tariffs appear to influence behavior of consumption. The estimated average water demand from municipal source in Bellavista is $86 \mathrm{lpcpd}$, while in Puerto Ayora it is $160 \mathrm{lpcpd}$ (Reyes et al., 2017). Furthermore, in the same study, the calculated total water demand (regarding other sources to compensate the lack of service and quality such as bottled-desalinated water, water from trucks and rainwater) in Puerto Ayora is 177 lpcpd and in Bellavista is 253 lpcpd. The difference in demand may not only be attributed to difference in tariff structure, but also because demand in Bellavista is highly compensated with rainwater harvesting. Furthermore, the high water demand from municipal system in Puerto Ayora may be attributed to the overwhelming quantity of spilling, because faucets are not closed after the storage tanks are already filled up, a common practice observed daily. Moreover, the majority of touristic facilities are located in Puerto Ayora, accounting for 55\% of the total water demand of the island.

\section{Methodology}

All the data and information analyzed was gathered during fieldwork period between September 2013 and January 2014. The analyses are based on the following activities performed during the fieldwork:

1) Interviews with relevant local authorities (Department of Potable Water and Sewage, National Secretariat of Water and Direction of the National Park of Galapagos);

2) Site visits to water supply networks in Puerto Ayora and Bellavista;

3) Surveys conducted to 349 premises including (i) domestic, (ii) commercial (restaurants and hotels) and (iii) laundries. These surveys covered several aspects regarding consumption from various types of sources, types of tariffs, payments, willingness to pay, wastewater treatment, among other subjects. Table 2 shows the samples sizes calculated for each category.

Table-2. Survey sample size per consumption category in Santa Cruz

\begin{tabular}{|c|c|c|c|c|}
\hline $\begin{array}{l}\text { Consumption } \\
\text { category }\end{array}$ & $\begin{array}{l}\text { Number of } \\
\text { properties }\end{array}$ & $\begin{array}{l}\text { Percentage } \\
\text { of total }(\%)\end{array}$ & $\begin{array}{l}\text { Optimal number of } \\
\text { surveys }\end{array}$ & $\begin{array}{l}\text { Actual number of } \\
\text { executed surveys }\end{array}$ \\
\hline $\begin{array}{l}\text { Puerto Ayora: } \\
\text { Domestic } \\
\text { Hotels } \\
\text { Food and Beverages } \\
\text { Laundries }\end{array}$ & $\begin{array}{l}1996 \\
159 \\
49 \\
5\end{array}$ & $\begin{array}{l}69 \\
6 \\
2 \\
0\end{array}$ & $\begin{array}{l}234 \\
19 \\
6 \\
1 \\
\end{array}$ & $\begin{array}{l}240 \\
29 \\
30 \\
16^{\mathrm{b}} \\
\end{array}$ \\
\hline $\begin{array}{l}\text { Bellavista: } \\
\text { Domestic }\end{array}$ & 435 & 15 & 51 & 59 \\
\hline Others (excluded) & 251 & 8 & - & - \\
\hline Total & 2895 & 100 & 310 & 374 \\
\hline
\end{tabular}

Note: ${ }^{\mathrm{a} C a l c u l a t e d}$ according to the procedure at http://www.surveysystem.com/sscalc.htm. ${ }^{\mathrm{b}}$ Includes not officially registered laundries.

Source: Reyes et al. (2017)

4) Data collection from relevant institutions such as prices, cadastres, etc.;

5) Analysis of surveys on payments, willingness to pay and overdue payments;

6) Development of scenarios with solutions regarding increase in current water tariffs, and new suggested tariff structures such as consumption-based and IBT;

7) Evaluation of a scenario including the investment of a desalination plant as part of the centralized system. 


\section{Average Costs of Water Supply in Santa Cruz}

Based on the information on average demand per category in Puerto Ayora from Reyes et al. (2017), total revenues per category for the municipality are shown in Table 3. This table shows revenues from the water cadastre of 2013 and an estimated actual price per cubic meter, based on average number of connections.

Table-3. Average revenues per month and per category in Puerto Ayora for the year 2013

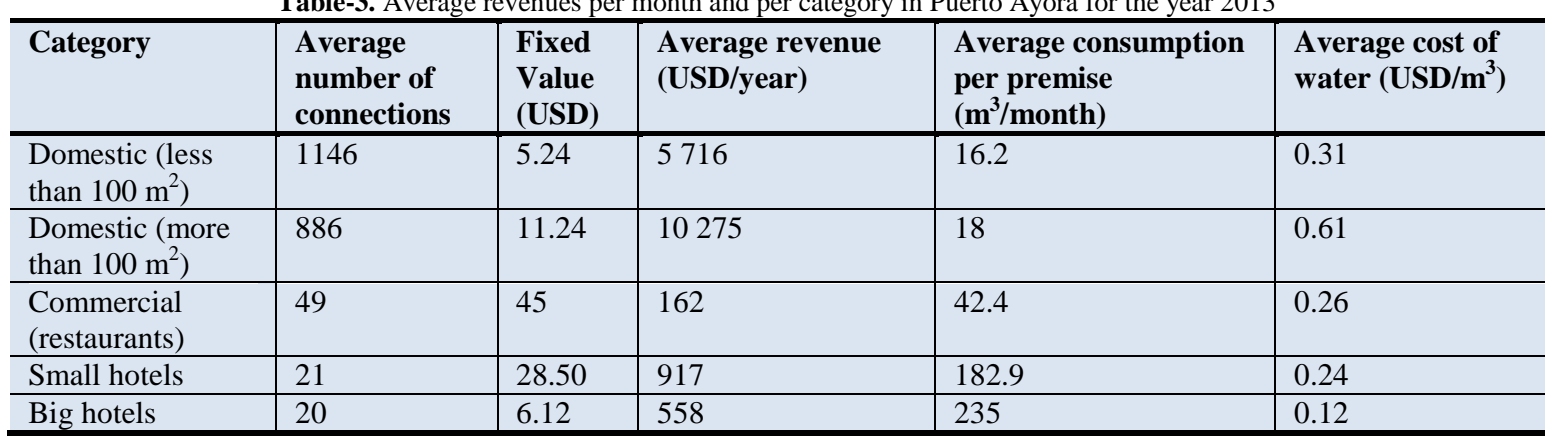

As observed on Table 3, revenues from fixed tariff structures in Puerto Ayora are significantly low, considering the actual volume of water consumption. The estimated price paid per cubic meter for all categories is low as well, considering the minimum salary for the islands, which is approximately $600 \mathrm{USD} / \mathrm{month}$. Therefore, the current payment of a water bill for a family receiving just one minimum salary would represent only $0.8 \%$ of the monthly income.

On the other hand, Bellavista is mainly considered domestic, since there are very few premises belonging to other categories. Since approximately $32 \%$ of water meters do not work properly (in 2013), the registered total consumption is significantly lower. Table 4 shows the average consumption per premise based on working meters, then compared to the collected revenues in order to calculate actual price of water per cubic meter.

Table-4. Actual price of water based on all water meters working in Bellavista

\begin{tabular}{l|l|l|l|l|l|l|l}
\hline Month & $\begin{array}{l}\text { Registered } \\
\text { Consumption } \\
\left(\mathbf{m}^{\mathbf{3}}\right)\end{array}$ & $\begin{array}{l}\text { No. of water } \\
\text { meters } \\
\text { registering } \\
\text { consumption }\end{array}$ & $\begin{array}{l}\text { No. of } \\
\text { meters not } \\
\text { registering } \\
\text { consumption }\end{array}$ & $\begin{array}{l}\text { Average } \\
\text { consumption/ } \\
\left.\text { premise } \mathbf{( m}^{\mathbf{3}}\right)\end{array}$ & $\begin{array}{l}\text { Real } \\
\text { calculated } \\
\text { consumption } \\
\left(\mathbf{m}^{\mathbf{3}}\right)^{*}\end{array}$ & $\begin{array}{l}\text { Total } \\
\text { billed } \\
(\mathbf{U S D})\end{array}$ & $\begin{array}{l}\text { Price of } \\
\text { water } \\
\left(\mathbf{U S D} / \mathbf{m}^{\mathbf{3}}\right)\end{array}$ \\
\hline January & 5,376 & 348 & 79 & 15 & 6,596 & 6,931 & 1.05 \\
\hline February & 5,370 & 345 & 83 & 16 & 6,662 & 6,926 & 1.04 \\
\hline March** & 330 & 25 & 404 & 13 & 5,666 & 829 & 0.15 \\
\hline April** & 441 & 12 & 407 & 37 & 15,391 & 952 & 0.06 \\
\hline May & 4,605 & 358 & 71 & 13 & 5,519 & 6,002 & 1.09 \\
\hline June & 6,513 & 360 & 72 & 18 & 7,816 & 8,313 & 1.06 \\
\hline July & 6,262 & 363 & 80 & 18 & 7,681 & 8,010 & 1.04 \\
\hline August & 5,559 & 352 & 82 & 16 & 6,854 & 7,160 & 1.04 \\
\hline September & 5,654 & 347 & 89 & 16 & 7,104 & 7,277 & 1.02 \\
\hline October & 5,654 & 347 & 90 & 16 & 7,120 & 7,278 & 1.02 \\
\hline November & 5,098 & 352 & 88 & 14 & 6,372 & 6,608 & 1.04 \\
\hline December & 4,965 & 356 & 87 & 14 & 6,178 & 6,450 & 1.04 \\
\hline AVERAGE & 5,506 & 352 & 82 & 16 & 6790 & 7096 & 1.05 \\
\hline
\end{tabular}

*Consumption calculated assuming all non working devices will register the average consumption for that month. ** These months were excluded from all average calculations since they do not represent a typical month

Table 4 shows that average actual payment per cubic meter is approximately USD 1.05, explained by the high percentage of non-working meters. Clearly, this issue contributes to extra financial burden to the municipality, since the expected revenues are even lower (connections with non-working meters are only charged USD 2.21 per month). These calculated values are considering theoretical revenues only, not taking into account yet the overdue bills.

Figure-1. (a) Payment of fixed tariffs per month in Puerto Ayora and (b) average payment of monthly water bills in Bellavista

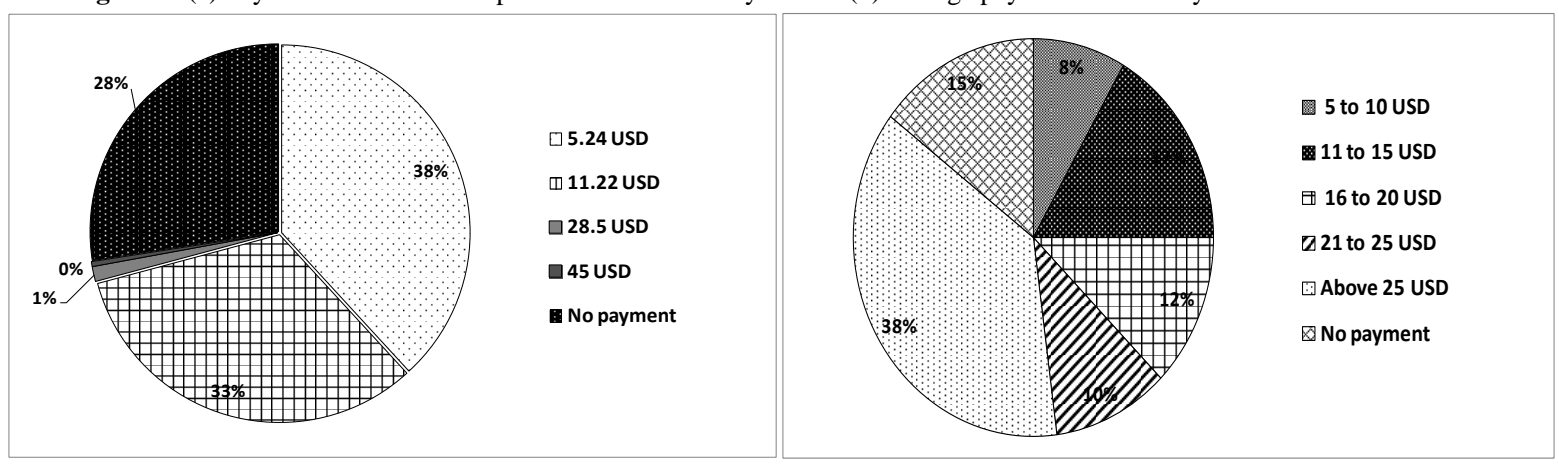


In the survey carried out by Reyes et al. (2017), an inquiry was made about the actual price people pay for water. As shown in Figure 1, 28\% of the population in Puerto Ayora and 17\% in Bellavista do not pay any water tariff at all. This matches with a further interview made to the DPWS, in which they confirmed not to suspend the water service in Puerto Ayora to premises that do not pay. They also explained that the department would need to fracture the streets and dig in order to suspend the service because there is no valve for each connection to shut it off. Due to lack of personnel and financial resources, this is hardly done. In theory, the penalty is suspension of the service after two months of no payment and an extra fee of USD 6 for the reconnection of the service, action which takes place only in Bellavista due to the presence of water meters. Nevertheless, this policy is not applied in Puerto Ayora and in reality there is no penalty for lack of payment of the monthly tariffs.

Furthermore, the overdue bills are an important obstacle for the municipality, especially in Puerto Ayora, where customers can not be disconnected for the water supply service. In 2013, the number of customers who did not pay on time increased by approximately $15 \%$, as shown in Figure 2. In the case of Bellavista, the percentage of overdue bills is significantly lower and showed a trend of decrease following the end of the year; tendency that can be attributed to metering.

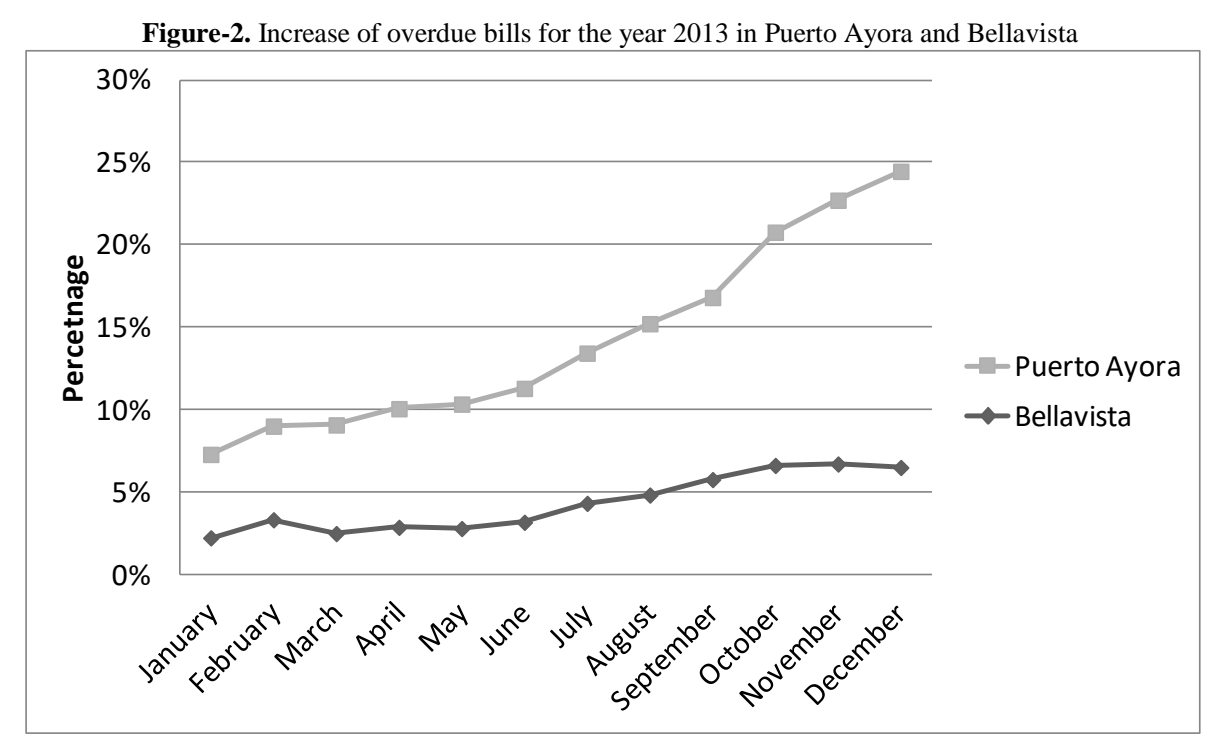

The figure implicitly explains the lack of proper management since the population appears to be increasingly encouraged not to pay in the absence of punitive measures. The rate of expansion of the settlement due to tourism growth, and the increase in number of water connections without any control measures will only contribute to increase this trend.

Based on further calculations and analysis based on costs of abstraction of water and bill emissions and collection, the total revenues for the municipality were estimated. The figures for total collected (USD) were calculated subtracting overdue bills and lack of payments. The cost of supplying water includes only operation and management costs for both settlements, and excludes a significant financial investment done by the municipality (Personal Communication, 2014).

Table-5. Financial deficit for Puerto Ayora and Bellavista

\begin{tabular}{l|l|l|l|l|l}
\hline Settlement & $\begin{array}{l}\text { Cost of supplied } \\
\text { water* (USD/year) }\end{array}$ & $\begin{array}{l}\text { Total billed } \\
\text { (USD/year) }\end{array}$ & $\begin{array}{l}\text { Total collected } \\
\text { (USD/year) }\end{array}$ & $\begin{array}{l}\text { Deficit with } \\
\text { total billed } \\
\text { (USD/year) }\end{array}$ & $\begin{array}{l}\text { Deficit with total } \\
\text { collected } \\
\text { (USD/year) }\end{array}$ \\
\hline Puerto Ayora & 993,384 & 211,538 & 190,926 & 781,846 & 802,458 \\
\hline Bellavista & 114,476 & 74,744 & 71,620 & 39,732 & 42,856 \\
\hline TOTAL & $1,107,860$ & 286,282 & 257,653 & 821,578 & 850,206 \\
\hline
\end{tabular}

*Considering only operations and management costs

\section{Analysis on Willingness to Pay, Payment of Bottled Water and Increase of Fixed Tariffs}

The water service provided by the municipality is low, and as a consequence the tariffs have been established with a low price. In a personal communication with the municipality, they affirmed not to increase prices of water due to a fear of rejection. Nevertheless, respondents from the survey said they are willing to pay more, conditioned to receiving a better service and better quality of water. The results of these affirmations are portrayed in Figure 3 . 
Figure-3. Percentages of surveyed households (a) willing to pay more for a better municipal service per month and (b) the amount willing to pay per month

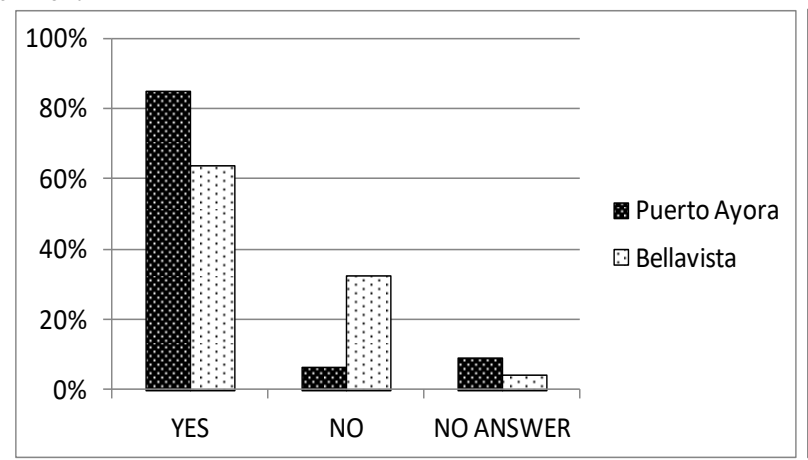

(a)

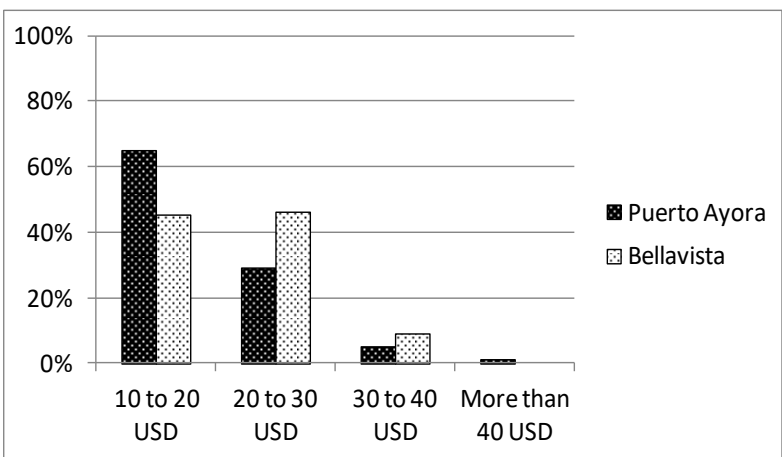

(b)

Figure 3(a) shows that more than $80 \%$ in Puerto Ayora and more than $60 \%$ in Bellavista are willing to increase their monthly payments in exchange for a more reliable service, as well as a better quality of supplied water. Figure 4(b) illustrates that more than $60 \%$ of the surveyed population in Puerto Ayora affirm to be willing to pay between 10 USD and 20 USD per month and approximately $30 \%$ of the surveyed families between 20 USD and 30 USD. In Bellavista, around $40 \%$ of the population is willing to pay within 10 USD an 20 USD, while the same percentage is willing to pay between 20 USD and 30 USD for an improved service. This suggests, in fact, that local population is aware that a better supply system will require an increase of current tariffs.

It is also important to analyze the actual total payment of water. These costs reflect the consumption of bottleddesalinated water, which is considered expensive. For example, in Puerto Ayora, 46\% pay between 5 and 10 USD per month for drinking (bottled-desalinated water). In Bellavista, the majority of household surveyed pay more than 20 USD per month for bottled water. The results for bottled water are shown in Figure 4.

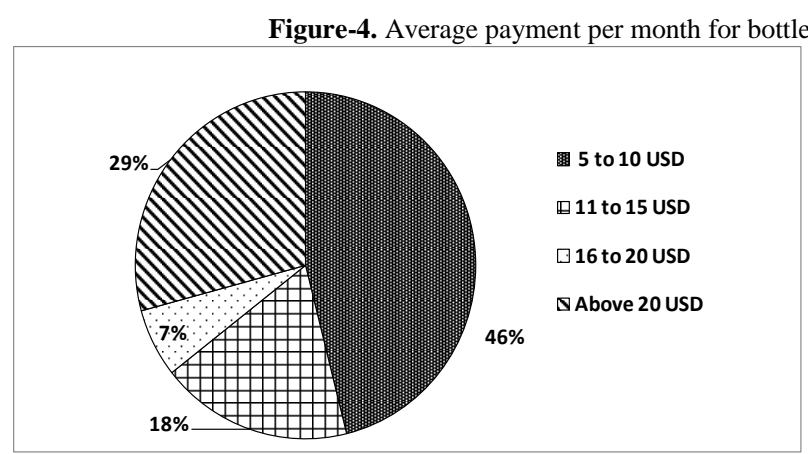

(a)

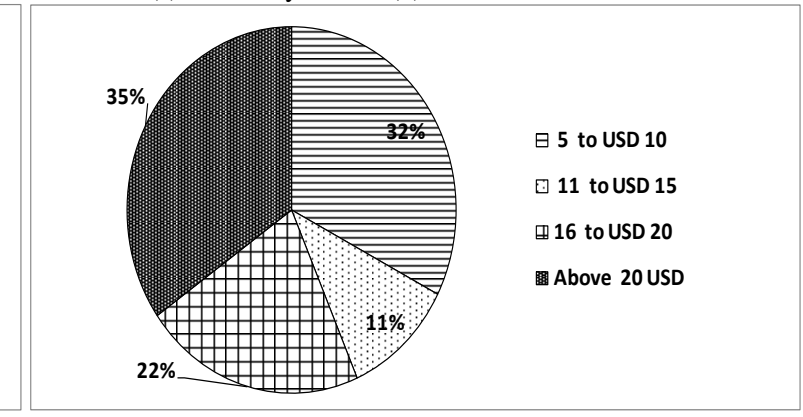

(b)

Figure 4 shows the distribution of monthly expenses per family for bottled water among surveyed population. This indicates that an average family pays significantly more for all water sources. Based on their willingness to pay and the actual payment, is possible to create several scenarios to analyze the increase in the revenues for the municipality as shown in Table 6.

Table-6. Various scenarios on increase of current water tariffs

\begin{tabular}{l|l|l|l|l}
\hline Settlement & $\begin{array}{l}\text { Total Billed for } \\
\mathbf{2 0 1 3}\end{array}$ & $\begin{array}{l}\text { Scenario 1 } \\
(\mathbf{2 0 \% )}\end{array}$ & $\begin{array}{l}\text { Scenario 2 } \\
(\mathbf{4 0 \% )}\end{array}$ & $\begin{array}{l}\text { Scenario 3 } \\
(\mathbf{6 0 \%})\end{array}$ \\
\hline Puerto Ayora & 211.538 & 380.768 & 528.844 & 634.613 \\
\hline Bellavista & 74.744 & 126.797 & 174.082 & 207.858 \\
\hline Total & $\mathbf{2 8 6 . 2 8 2}$ & $\mathbf{5 0 7 . 5 6 5}$ & $\mathbf{7 0 2 . 9 2 7}$ & $\mathbf{8 4 2 . 4 7 0}$ \\
\hline Deficit 1* & $\mathbf{2 . 8 9 2 . 5 4 7}$ & $\mathbf{2 . 6 7 1 . 2 6 4}$ & $\mathbf{2 . 4 7 5 . 9 0 2}$ & $\mathbf{2 . 3 3 6 . 3 5 8}$ \\
\hline Deficit 2** & $\mathbf{8 2 1 . 5 7 8}$ & $\mathbf{6 0 0 . 2 9 5}$ & $\mathbf{4 0 4 . 9 3 3}$ & $\mathbf{2 6 5 . 3 8 9}$ \\
\hline
\end{tabular}

Source: Water Cadastre of 2013 of the Municipality of Santa Cruz.*Includes investment costs** Only operations and management costs

As observed in Table 6, even when the tariffs would increase by $60 \%$, the deficit for the municipality does not decrease significantly, as expected. In the case of the second deficit, the cost cannot be covered even when the water bills are increased by $100 \%$. This fact suggests that water tariff structures need to be completely reformulated. However, in order to increase the tariffs drastically, the service would need to improve proportionally. Since the municipality has limited means to improve the service, due to limited revenues, the situation is in vicious circle. 


\section{Development of Scenarios with Different Water Tariff Structure 7.1. Scenario with Linear (Volumetric) Tariff}

Based on the results from the previous section, increasing current tariffs up to $60 \%$ would not suffice for the municipality to increase significantly their revenues. Therefore, other tariff structures have been proposed. In Table 6 , a linear tariff is suggested, where payments are directly proportional to consumption. The cost per cubic meter was assumed as the same current price as in Bellavista $\left(1.21 \mathrm{USD} / \mathrm{m}^{3}\right)$. Also, an investment of water meter installation of 151 USD per water meter was considered (Personal Communication, 2014). Furthermore, based on results on specific demand from the different categories from the survey, published in Reyes et al. (2015), the results on revenues for the municipality are as shown in Table 7. These averages were calculated based on the estimation of surveyed people on the volume of their storage tanks and the times of filling per week.

Table-7. New calculated revenue for the municipality with Linear Tariff Structure

\begin{tabular}{|c|c|c|c|c|}
\hline Category & $\begin{array}{l}\text { Average consumption } \\
\text { per premise } \\
\text { (m3/month) }\end{array}$ & $\begin{array}{l}\text { Average no. of } \\
\text { connections }\end{array}$ & $\begin{array}{l}\text { Corrected number of } \\
\text { premises* }\end{array}$ & $\begin{array}{l}\text { Revenue with Linear } \\
\text { Tariff (USD/year) }\end{array}$ \\
\hline $\begin{array}{l}\text { Domestic (less than } \\
100 \mathrm{~m}^{2} \text { ) }\end{array}$ & 16.2 & 1145.9 & 1,146 & 269,666 \\
\hline $\begin{array}{l}\text { Domestic (more than } \\
100 \mathrm{~m}^{2} \text { ) }\end{array}$ & 18.0 & 886.0 & 443 & 115,629 \\
\hline $\begin{array}{l}\text { Commercial } \\
\text { (Restaurants) }\end{array}$ & 42.4 & 49.0 & 492 & 303,103 \\
\hline Small Hotels & 182.9 & 20.5 & 80 & 212,407 \\
\hline Big hotels & 235.0 & 19.8 & 80 & 272,927 \\
\hline \multirow[t]{4}{*}{ Bellavista } & 15.0 & 444.0 & 444 & \begin{tabular}{|l|}
96,703 \\
\end{tabular} \\
\hline & & & TOTAL & \begin{tabular}{|l|}
$1,270,436$ \\
\end{tabular} \\
\hline & & & $\begin{array}{l}\text { WATER METER } \\
\text { INVESTMENT }\end{array}$ & 338,391 \\
\hline & & & TOTAL REVENUE & 932,045 \\
\hline
\end{tabular}

* Refers to estimation of what could be the actual number of connections per category, since the average number according to the municipality is not accurate.

If tariffs are changed to the same scheme as in Bellavista, the revenue for the municipality will increase significantly. However, a large investment for water meter installation is needed and this will decrease the revenues once more. Nevertheless, in the following year the revenues would increase in a more significant way, since the water meter investment would only be done once.

\subsection{Scenario with Implementation of Increasing Block Tariff (IBT)}

With an IBT structure, major consumers would pay more, specially at the higher blocks of consumption Table 8 shows a potential IBT structure, where the base tariff refers to a fixed cost to any consumption within the range of the first block. The following blocks reflect the cost per cubic meter after the base tariff has been exceeded. Therefore, when the consumption increases, so does the cost per cubic meter. The base tariffs for the fists block for the major consumers start with higher costs because these categories account for more than half of total demand (Reyes et al., 2015). The average payment per premise per category was calculated based on the average demand per premise shown in Table 7. The costs selected are similar to the ones already applied in Bellavista, so there would not be an excessive rejection.

Table-8. Suggested Increasing Block Tariffs in Puerto Ayora

\begin{tabular}{l|l|l|l}
\hline & Ranges $(\mathbf{m 3})$ & Cost (USD) & Average payment per category \\
\hline DOMESTIC & & & \\
\hline Base tariff & $1-8$ & 5 & $\begin{array}{l}\left(\text { less than } 100 \mathrm{~m}^{2}\right)=14 \text { USD/month } \\
* \text { Based on average demand of } 16.2\end{array}$ \\
\hline Block 1 & $>8-15$ & $1.1 / \mathrm{m}^{3}$ & $\mathrm{~m}^{3} /$ premise \\
\hline Block 2 & $>15-20$ & $1.3 / \mathrm{m}^{3}$ & $\left(\right.$ more than $\left.100 \mathrm{~m}^{2}\right)=16.6$ USD/month \\
\hline Block 3 & $>20-25$ & $1.5 / \mathrm{m}^{3}$ & $*$ Based on average demand of 18 \\
\hline Block 4 & $>25-30$ & $1.7 / \mathrm{m}^{3}$ & $\mathrm{~m}^{3} /$ premise \\
\hline COMMERCIAL & & & \\
\hline Base tariff & $1-10$ & 8 & \\
\hline Block 1 & $>10-20$ & $1.1 / \mathrm{m}^{3}$ & \\
\hline Block 2 & $>20-30$ & $1.3 / \mathrm{m}^{3}$ & 50.4 USD/month \\
\hline Block 3 & $>30-40$ & $1.5 / \mathrm{m}^{3}$ & $*$ Based on average demand of 42.4 \\
\hline Block 4 & $>40-50$ & $1.7 / \mathrm{m}^{3}$ & $\mathrm{~m}^{3} /$ premise \\
\hline $\begin{array}{l}\text { RESIDENTIAL } \\
\text { (Small hotels) }\end{array}$ & & & \\
\hline Base tariff & $1-20$ & 15 & \\
\hline Block 1 & $>20-60$ & $1.3 / \mathrm{m}^{3}$ & \\
\hline Block 2 & $>60-120$ & $1.5 / \mathrm{m}^{3}$ & 270 USD/month \\
\hline Block 3 & $>120-150$ & $1.7 / \mathrm{m}^{3}$ & $*$ Based on average demand of 182.9 \\
\hline
\end{tabular}




\begin{tabular}{l|l|l|l}
\hline Block 4 & $>150-200$ & $1.9 / \mathrm{m}^{3}$ & $\mathrm{~m}^{3} /$ premise \\
\hline $\begin{array}{l}\text { INDUSTRIAL } \\
\text { (Big hotels) }\end{array}$ & & & \\
\hline Base tariff & $1-30$ & 25 & \\
\hline Block 1 & $>30-80$ & $1.4 / \mathrm{m}^{3}$ & \\
\hline Block 2 & $>80-150$ & $1.6 / \mathrm{m}^{3}$ & $356 \mathrm{USD} / \mathrm{month}$ \\
\hline Block 3 & $>150-220$ & $1.8 / \mathrm{m}^{3}$ & *Based on average demand of 253 \\
\hline Block 4 & $>220-300$ & $2 / \mathrm{m}^{3}$ & $\mathrm{~m}^{3} /$ premise \\
\hline
\end{tabular}

The new revenue for the municipality with an IBT structure was calculated, considering the same water meter installation investment as the previous scenario. These results are shown in Table 9. The total revenue for the municipality was calculated based on the average payment per premise for each category, which was based on average consumption per household and the number of connections for each category.

Table-9. New calculated revenue for the municipality with IBT

\begin{tabular}{l|l|l|l|l|l}
\hline Category & $\begin{array}{l}\text { Average payment } \\
\text { per premise } \\
\text { (USD/month) }\end{array}$ & $\begin{array}{l}\text { Average } \\
\text { number of } \\
\text { connections }\end{array}$ & $\begin{array}{l}\text { Corrected } \\
\text { number of } \\
\text { connections* }\end{array}$ & $\begin{array}{l}\text { Revenue with IBT } \\
\text { (USD/year) }\end{array}$ & $\begin{array}{l}\text { Revenue with IBT and } \\
\text { corrected number of } \\
\text { connections (USD/year) }\end{array}$ \\
\hline $\begin{array}{l}\text { Domestic (less } \\
\left.\text { than } 100 \mathrm{~m}^{2}\right)\end{array}$ & 14 & 1,146 & 1,146 & 192,514 & 192,514 \\
\hline $\begin{array}{l}\text { Domestic (more } \\
\left.\text { than } 100 \mathrm{~m}^{2}\right)\end{array}$ & 16.6 & 886 & 443 & 176,491 & 176,491 \\
\hline $\begin{array}{l}\text { Commercial } \\
\text { Restaurants) }\end{array}$ & 50.4 & 49 & 492 & 29,635 & 297,562 \\
\hline Small hotels & 270 & 21 & 80 & 66,592 & 258,248 \\
\hline Big hotels & 356 & 20 & 80 & 84,728 & 339,624 \\
\hline Bellavista & 12.7 & 444 & 444 & 67,666 & 67,666 \\
\hline & & & & TOTAL & $\mathbf{1 , 3 3 2 , 1 0 4}$ \\
\hline & & & & $\begin{array}{l}\text { WATER METER } \\
\text { INVESTMENT }\end{array}$ & $\mathbf{3 3 8 , 3 9 1}$ \\
\hline & & & $\begin{array}{l}\text { TOTAL } \\
\text { REVENUE }\end{array}$ & $\mathbf{1 , 6 7 0 , 4 9 5}$ \\
\hline
\end{tabular}

*Refers to estimation of what could be the actual number of connections per category, since the average number according to the municipality is not accurate.

Table 8 presents the suggested increasing block tariff for Puerto Ayora. Since hotels are the major consumers and account for $55 \%$ of the total water demand (Reyes et al., 2015), this tariff structure seems to fit, making major consumers to subsidize the lower consumers. With such an increase, the municipality will almost cover operations and management costs, including the investment for water meter installation. It is important to mention that the even at this tariff water supplied would still be of non-drinking quality.

\subsection{Implication of Water Tariff in Case of the Installation of a Centralized Desalination Plant}

The previous results from both tariff structure scenarios have not considered yet quality of the water. Therefore, a desalination plant has been considered as the most suitable strategy that will cover the total demand of local population. For the installation of such treatment, several costs should be considered, with an expected lifetime of the project of 30 years. The important factors that influence this installation are shown in Table 10.

\begin{tabular}{l|l}
\hline Table-10. Costs for the municipality if a desalination plant would be installed \\
\hline Item & Cost (USD) \\
\hline $\begin{array}{l}\text { Capital cost of desalination of BW } \\
\left(10,000 \mathrm{~m}^{3} / \text { day }\right)^{*}\end{array}$ & $26,500,000$ \\
\hline $\begin{array}{l}\text { Average cost of desalination of } \\
\text { Brackish water/ } \mathrm{m}^{3 *}\end{array}$ & 0.3 \\
\hline Water meter installation & 400,000 \\
\hline $\begin{array}{l}\text { Pumping costs based on the year } \\
\text { 2014 }\end{array}$ & $1,107,859$ \\
\hline Inflation rate & $2 \%$ \\
\hline Interest rate & $5 \%$ \\
\hline
\end{tabular}

*Source: (Wittholz et al., 2008)

Assuming that the municipality would take a loan, an analysis was made to calculate the payback, the interest costs and the position after payback for a project period of 30 years (situations at five years intervals are presented in to avoid extensive table) (Table 11). 
Table-11. Calculation of payback and interest cost for a desalination plant project

\begin{tabular}{l|l|l|l|l}
\hline Year & Position after payback & Interest cost & Payback & Total \\
\hline 2015 & $26,500,000$ & $1,325,000$ & 350,000 & $1,675,000$ \\
\hline 2020 & $24,566,029$ & $1,249,573$ & 425,427 & $1,675,000$ \\
\hline 2025 & $22,097,738$ & $1,132,035$ & 542,965 & $1,675,000$ \\
\hline 2030 & $18,947,503$ & 982,024 & 692,976 & $1,675,000$ \\
\hline 2035 & $14,926,916$ & 790,567 & 884,433 & $1,675,000$ \\
\hline 2040 & $9,795,515$ & 546,215 & $1,128,785$ & $1,675,000$ \\
\hline 2045 & $3,246,403$ & 234,353 & $1,440,647$ & $1,675,000$ \\
\hline
\end{tabular}

Based on the values of the previous table, different calculations have been done in order to calculate the total costs, considering investment costs (depreciation and interest) and other costs which includes maintenance costs per category based on demand (assumed to be $0.3 \mathrm{USD} / \mathrm{m}^{3}$ ) and pumping costs. These calculations are shown in Table 12. For this, inflation was considered over the pumping costs known for 2014 and assuming an interest of the loan for such a project of a 5\% over the period of revenue recover (30 years) and other factors. Furthermore, three scenarios were assumed as fast, medium and low population growth with annual growth of $9 \%, 4.7 \%$ and $1.5 \%$ (Mena et al., 2013), respectively. These annual percentages were assumed for population growth as well as for hotels and restaurants in order to calculate the demand per year based on the current demand.

Table-12. Total costs for all demand categories for fast, medium and slow population growth

\begin{tabular}{|c|c|c|c|c|c|c|c|}
\hline \multirow[b]{2}{*}{ Year } & \multicolumn{2}{|c|}{ Investment Costs } & \multicolumn{4}{|c|}{ Other Costs } & \multirow[b]{2}{*}{ Total } \\
\hline & -depreciation & -interest & domestic & commercial & hotels & pumping cost & \\
\hline \multicolumn{8}{|c|}{ FAST POPULATION GROWTH SCENARIO } \\
\hline 2015 & 883,333 & $1,325,000$ & 218,013 & 6,233 & 98,400 & $1,161,526$ & $3,692,505$ \\
\hline 2020 & 883,333 & $1,132,035$ & 429,319 & 11,721 & 220,248 & $2,380,636$ & $5,057,292$ \\
\hline 2025 & 883,333 & $1,132,035$ & 429,319 & 11,721 & 220,248 & $2,380,636$ & $5,057,292$ \\
\hline 2030 & 883,333 & 982,024 & 602,461 & 16,447 & 344,596 & $3,468,612$ & $6,297,473$ \\
\hline 2035 & 883,333 & 790,567 & 845,429 & 23,078 & 539,148 & $5,067,562$ & $8,149,119$ \\
\hline 2040 & 883,333 & 546,215 & $1,186,386$ & 32,383 & 843,542 & $7,424,321$ & $10,916,180$ \\
\hline 2045 & 883,333 & 234,353 & $1,664,848$ & 45,441 & $1,319,790$ & $10,908,285$ & $15,056,050$ \\
\hline \multicolumn{8}{|c|}{ MEDIUM POPULATION GROWTH SCENARIO } \\
\hline 2015 & 883,333 & $1,325,000$ & 226,640 & 6,233 & 98,400 & $1,056,820$ & $3,596,426$ \\
\hline 2020 & 883,333 & $1,249,573$ & 249,289 & 7,371 & 116,377 & $1,193,605$ & $3,699,549$ \\
\hline 2025 & 883,333 & $1,132,035$ & 274,137 & 9,092 & 143,535 & $1,372,134$ & $3,814,265$ \\
\hline 2030 & 883,333 & 982,024 & 301,390 & 11,213 & 177,031 & $1,582,143$ & $3,937,134$ \\
\hline 2035 & 883,333 & 790,567 & 331,276 & 13,830 & 218,343 & $1,829,973$ & $4,067,322$ \\
\hline 2040 & 883,333 & 546,215 & 364,040 & 17,058 & 269,296 & $2,123,347$ & $4,203,288$ \\
\hline 2045 & 883,333 & 234,353 & 399,952 & 21,038 & 332,139 & $2,471,685$ & $4,342,500$ \\
\hline \multicolumn{8}{|c|}{ LOW POPULATION GROWTH SCENARIO } \\
\hline 2015 & 883,333 & $1,325,000$ & 220,722 & 6,233 & 98,400 & $1,036,600$ & $3,570,289$ \\
\hline 2020 & 883,333 & $1,249,573$ & 234,635 & 6,605 & 104,272 & $1,100,675$ & $3,579,092$ \\
\hline 2025 & 883,333 & $1,132,035$ & 249,425 & 7,101 & 112,106 & $1,174,885$ & $3,558,886$ \\
\hline 2030 & 883,333 & 982,024 & 265,147 & 7,635 & 120,530 & $1,254,137$ & $3,512,806$ \\
\hline 2035 & 883,333 & 790,567 & 281,860 & 8,208 & 129,586 & $1,338,774$ & $3,432,330$ \\
\hline 2040 & 883,333 & 546,215 & 299,627 & 8,825 & 139,323 & $1,429,166$ & $3,306,490$ \\
\hline 2045 & 883,333 & 234,353 & 318,514 & 9,488 & 149,791 & $1,525,707$ & $3,121,186$ \\
\hline
\end{tabular}

The average cost per $\mathrm{m}^{3}$ was also calculated based on the total demand, total number of premises (including the three categories) and the total cost for the municipality. These analyses are shown in Table 13. In order for the municipality to have a lower economical burden, hotels could contribute to part of the cost by charging and extra charge per bed. This would not generate a very significant amount, but would lower the debt. Also, IBT should be considered if a desalination plant would be installed. In this way, the major consumers (hotels) would pay more and the cost per cubic meter for the domestic category could be lowered down.

Table-13. Analysis of investment of a desalination plant over a 30 year period

\begin{tabular}{|c|c|c|c|c|}
\hline \multicolumn{5}{|c|}{ Fast population growth (9\% annual increase) } \\
\hline Year & \begin{tabular}{|l|}
$\begin{array}{l}\text { Cost for the municipality } \\
\text { (USD) }\end{array}$ \\
\end{tabular} & $\begin{array}{l}\begin{array}{l}\text { Total number of } \\
\text { premises }\end{array} \\
\end{array}$ & $\begin{array}{l}\text { Average water bill per month } \\
\text { (USD) }\end{array}$ & $\begin{array}{l}\text { Average cost per } \mathbf{m}^{3} \\
\text { (USD) }\end{array}$ \\
\hline 2015 & $3,692,505$ & 2,122 & 145 & 2.86 \\
\hline 2020 & $4,226,185$ & 3,265 & 108 & 2.32 \\
\hline 2025 & $5,057,292$ & 5,024 & 84 & 1.91 \\
\hline 2030 & $6,297,473$ & 7,729 & 68 & 1.63 \\
\hline 2035 & $8,149,119$ & 11,893 & 57 & 1.45 \\
\hline 2040 & $10,916,180$ & 18,298 & 50 & 1.32 \\
\hline 2045 & $15,056,050$ & 28,154 & 45 & 1.24 \\
\hline \multicolumn{5}{|c|}{ Medium population growth (4.7\% annual growth) } \\
\hline Year & $\begin{array}{l}\text { Cost for the municipality } \\
\text { (USD) }\end{array}$ & $\begin{array}{l}\text { Total number of } \\
\text { premises }\end{array}$ & $\begin{array}{l}\text { Average water bill/ month } \\
\text { (USD) }\end{array}$ & $\begin{array}{l}\text { Average cost per } \mathbf{m}^{3} \\
\text { (USD) }\end{array}$ \\
\hline
\end{tabular}




\begin{tabular}{l|l|l|l|l}
\hline 2015 & $3,596,426$ & 2,122 & 141 & 2.71 \\
\hline 2020 & $3,699,549$ & 2,676 & 115 & 2.48 \\
\hline 2025 & $3,814,265$ & 3,375 & 94 & 2.23 \\
\hline 2030 & $3,937,134$ & 4,257 & 77 & 2.01 \\
\hline 2035 & $4,067,322$ & 5,368 & 63 & 1.80 \\
\hline 2040 & $4,203,288$ & 6,770 & 52 & 1.62 \\
\hline 2045 & $4,342,500$ & 8,538 & 42 & 1.44 \\
\hline Low population growth (1.5\% annual growth) & $\begin{array}{l}\text { Total number of } \\
\text { premises }\end{array}$ & $\begin{array}{l}\text { Average water bill per } \\
\text { month (USD) }\end{array}$ & $\begin{array}{l}\text { Average cost per } \mathbf{~ m}^{3} \\
\text { (USD) }\end{array}$ \\
\hline Year & $\begin{array}{l}\text { Cost for the municipality } \\
\text { (USD) }\end{array}$ & 2,122 & 140 & 3.10 \\
\hline 2015 & $3,570,289$ & 2,286 & 130 & 2.93 \\
\hline 2020 & $3,579,092$ & 2,463 & 120 & 2.73 \\
\hline 2025 & $3,558,886$ & 2,653 & 110 & 2.52 \\
\hline 2030 & $3,512,806$ & 2,858 & 100 & 2.31 \\
\hline 2035 & $3,432,330$ & 3,079 & 89 & 2.08 \\
\hline 2040 & $3,306,490$ & 8,538 & 42 & 1.44 \\
\hline 2045 & $4,342,500$ & \multicolumn{2}{l}{} \\
\hline
\end{tabular}

As shown in the Table 13, the investment on a desalination plant will increase drastically the prices on the water tariffs in order to cover investment and maintenance costs. In the three population scenarios, the cost per cubic meter tends to decrease by 2045, compared to year 2015. This is due to the increase on number of premises and in water demand, because the total cost for the municipality would be divided between more premises. In the fast growth scenario, the average price per cubic meter for 2045 is considerably low, but in this case the highest demand will occur, decreasing the average price. In summary, the average cost of the water bill per premise seems quite elevated, nevertheless, there is no differentiation made between categories. This high values of water bills in the case of the installation of a desalination plant gives an example of how important an IBT would be, where major consumers such as hotels, would pay more. If hotels subsidize somehow part of the investment cost, the domestic water bills will reduce as well.

\section{Conclusions}

This paper analyzed the financial impacts of current water tariff structures on the Municipality of Santa Cruz. Also, it evaluated several scenarios of increase in revenue with the change of tariffs. Furthermore, it assessed the implementation of a desalination plant and the implications on the costs of water. Based on this, several conclusions have been drawn:

-There is a lack of proper management regarding the collection of water bills. The municipality could increase their revenues and lower their deficit if standardized penalties would be established for non-paying customers and spilling tanks, as well as the suspension of the service when necessary. However, numerous factors allow the inefficiency of the service to continue, blocking its improvement. As a result, authorities do not dare to increase tariffs or change the structures because of a possible reaction from local population.

- Even though local population affirms to be willing to pay more on their monthly water bills, this is subjected to a better service and potable water. Therefore, the fixed tariffs in Puerto Ayora should be abolished and water meters must be installed for all connections, in order to increase revenues and lower demand.

-Simply increasing current fixed tariffs would not be sufficient to cover the deficit of the municipality. Therefore a linear tariff structure or an IBT would be required. An IBT is preferable as it promotes water demand management and major consumers would pay significantly more.

- In order to produce potable water and cover the total demand, a desalination plant would be the most suitable option for Santa Cruz Island. However, the costs of water would increase substantially and this may not be accepted by local population. Nevertheless, part of the desalination investment could be paid by the major consumers, mainly hotels, which may increase their rooms' rates and allocate a percentage to the desalination plant investment. Also, the investment could be covered partly with a loan, and partly with a percentage of the entrance fee to the Galapagos National Park (USD 100 per person).

-It is essential that the municipality communicates to local population future actions regarding modification of water tariffs and explain the objectives and goals, as well as the procedure of the transition period. Water bills should be modified and increased gradually, in several years, to avoid extreme discontent among local population. The political issue has presented a problem, since authorities do not change tariffs to avoid population rejection.

\section{References}

Bailey, R. and Buckley, C., 2005. "Modelling domestic water tariffs." In Presentation to the University of KwaZuluNatal Centre for Civil Society Durban, 7.

Banerjee, S., Foster, V., Ying, Y., Skilling, H. and Wodon, Q. (2010). Cost recovery, equity, and efficiency in water tariffs: evidence from African utilities. Policy research working paper from the World Bank. African Region-Sustainable Development Division.

Boland, J. J. and Whittington, D. (1998). The political economy of increasing block tariffs in developing countries. In world bank sponsored workshop on political economy of water pricing implementation. Washington, DC. 
d'Ozouville, N. and Merlen, G. (2007). Agua Dulce o la supervivencia en Galápagos. Galápagos: Migraciones, economía, cultura, conflictos y acuerdos. Biblioteca de Ciencias Sociales, 57(1): 297-313.

Direccion del Parque Nacional Galapagos (2014). Stadistics of Visitors to Galapagos. Santa Cruz-Galápagos: DPNG.

Gobierno Autonomo Descentralizado del Municipio de Santa Cruz (2013). Catastro de consumo de agua. Santa Cruz- Galápagos.

Liu, J. (2011). Investigación de la Calidad Bacteriológica del Agua y de las Enfermedades Relacionadas al Agua en la Isla Santa Cruz - Galápagos. Santa Cruz- Galápagos: Fundación Charles Darwin. Comisión Fullbright.

Mena, C., Walsh, S., Pizzitutti, F., Reck, G., Rindfuss, R., Orellana, D., Granda, V., Valle, C., Quiroga, D., García, J., Vasconez, L., Alexandra, G., Sanchez, M., Frizelle, B. and Tippett, R. (2013). Determination of social, environmental and economic relations which allow the development based on different processes of modeling, potential scenarios of sustainability of the socio-ecological system of the Galapagos Islands with emphasis on the dynamic of the flux of tourist visitors. Ministry of Environment \& Galapagos National Park. 1: Galapagos.

Reyes, M., Trifunovic, N., Sharma, S. and Kennedy, M., 2015. "Water supply and demand in Santa Cruz Island/Galápagos Archipelago." In XVth International Water Technology Conference. Sharm El SheikhEgypt (12-15 March 2015), International Water Techonology Association.

Reyes, M., Trifunovic, N., D' Ozouville, Sharma, S. and Kennedy, M. (2017). Quantification of Urban Water Demand in the Island of Santa Cruz (Galápagos Archipelago). Desalination and Water Treatment, 64(1): 111.

Sarango, D. (2013). 'Interview water supply sytem', in Maria Fernanda Reyes (ed.).

Wittholz, M. K., O'Neill, B. K., Colby, C. B. and Lewis, D. (2008). Estimating the cost of desalination plants using a cost database. Desalination, 229(1-3): 10-20.

Zetland, D. and Gasson, C. (2013). A global survey of urban water tariffs: are they sustainable, efficient and fair? International Journal of Water Resources Development, 29(3): 327-42. 